\title{
Monitoring results of population Alternaria genus in potato crops
}

\author{
Wyniki monitorowania populacji grzybów z rodzaju Alternaria \\ w uprawach ziemniaka
}

\author{
Hanna Gawińska-Urbanowicz, Józefa Kapsa
}

\begin{abstract}
Summary
Early blight, caused by Alternaria species: A. alternata and A. solani is a common potato disease. In 2008-2012, it was recorded in 81.9\% of observed potato crops in Poland. The results from field trials on efficacy of selected fungicides in control of early blight on potatoes show high differentiation. It might be partially related to control technique but also contents of pathogen population occurring in potato fields. In two years: 2011 and 2012, in three locations (Bonin, Przytocko and Mierzym) spore traps were used for collecting spores of Alternaria fungi and collected material was evaluated for frequency occurrence of Alternaria species. In both years, in all locations some seasonal fluctuations in occurrence of both Alternaria species were observed. Quantity ratio of occurrence of both pathogens in different locations varies throughout the season and was dependent upon climatic conditions. Nevertheless, microscopic analyzes revealed that in $2011-74 \%$ of spores were $A$. alternata and $26 \%$ A. solani and in the $2012-89 \%$ of spores were A. alternata and only $11 \% A$. solani. These results confirmed that $A$. alternata dominates during the growing season in the northern part of Poland.
\end{abstract}

Key words: potato, disease, early blight, pathogens, Alternaria species

\section{Streszczenie}

Alternarioza, wywoływana przez gatunki grzyba Alternaria: A. alternata i A. solani jest powszechnie występującą chorobą ziemniaka. W latach 2008-2012, w Polsce stwierdzano jej objawy na 81,9\% obserwowanych plantacjach ziemniaka. Wyniki polowych badań nad oceną skuteczności wybranych fungicydów w ochronie ziemniaka przed alternariozą wykazują duże zróżnicowanie. Może być to częściowo spowodowane technikami zwalczania, ale także składem populacji patogenu, występujących w uprawie ziemniaka. W ciągu dwóch lat 2011 i 2012, w trzech lokalizacjach (Bonin, Przytocko and Mierzym) zastosowano pułapki do kolekcjonowania zarodników grzybów rodzaju Alternaria, a zebrany materiał oceniano pod kątem częstości występowania gatunków należących do Alternaria. W obu latach, we wszystkich miejscowościach obserwowano sezonowe wahania w występowaniu obu gatunków. W różnych miejscowościach, stosunek ilościowy obu patogenów różnił się w ciągu całego sezonu i był zależny od warunków klimatycznych. Analizy mikroskopowe ujawniły, że w sezonie 2011 zebrano $74 \%$ zarodników A. alternata i $26 \%$ A. solani, a w roku 2012 - $89 \%$ zarodników A. alternata i tylko $11 \%$ A. solani. Wyniki te potwierdzają, że A. alternata dominuje w sezonie wegetacyjnym w północnym rejonie Polski.

Słowa kluczowe: ziemniak, choroba, alternarioza, patogeny, gatunki Alternaria

Instytut Hodowli i Aklimatyzacji Roślin - Państwowy Instytut Badawczy

Zakład Nasiennictwa i Ochrony Ziemniaka

76-009 Bonin 3

jkapsa@wp.pl 


\section{Wstęp / Introduction}

W związku z ociepleniem klimatu, obserwuje się dużą zmienność wśród patogenów roślinnych występujących na plantacjach ziemniaczanych. Zmiany w populacjach patogenów odpowiedzialnych za wywoływanie chorób na roślinach ziemniaka stwarzają różnorodne, nowe problemy w ich uprawach, m.in. moga zmniejszać skuteczność stosowanej ochrony.

Od kilkunastu lat coraz większego znaczenia w uprawach ziemniaka nabierają grzyby rodzaju Alternaria sprawcy alternariozy (Kapsa i Osowski 2004; Hausladen i Leiminger 2007). Alternarioza wywoływana przez dwa gatunki tego grzyba, a mianowicie Alternaria solani (A.s.) i Alternaria alternata (A.a.) pojawia się w tych rejonach uprawy ziemniaka, w których obserwuje się wysokie temperatury oraz przemiennie okresy suchej i wilgotnej pogody. Oprócz warunków pogodowych rozwojowi choroby sprzyjają wszystkie czynniki, które wpływają na osłabienie roślin na polu, takie jak fizjologiczne starzenie się roślin (Rotem 1966), mała zawartość substancji organicznej w glebie, niedostateczne nawożenie azotowe (Gudmestad i Pasche 2007), wcześniejsze infekcje roślin przez inne patogeny np. wirusy (Nagaich i Prased 1971).

Przyjmuje się, że w uprawach ziemniaka w Polsce dominującym gatunkiem jest A. alternata (Kuczyńska 1992; Kapsa 2007). Przeprowadzone obserwacje wskazują na częstsze występowanie grzyba A. alternata także w Niemczech, szczególnie na początku sezonu wegetacyjnego (Hausladen i wsp. 2004; Hausladen i Leiminger 2007; Leiminger i wsp. 2010). W innych krajach, takich jak Stany Zjednoczone czy Holandia za dominujący gatunek uznaje się gatunek A. solani (Johnson i wsp. 1986; Shtienberg i wsp. 1996; Bouwmann i Rijkers 2004; Wiik 2004; Gudmestad i Pasche 2007).

Wyniki doświadczeń laboratoryjnych i polowych, wykonanych wcześniej w Instytucie Hodowli i Aklimatyzacji Roślin - Państwowym Instytucie Badawczym w Boninie wskazują na różną skuteczność tych samych fungicydowych substancji czynnych w stosunku do poszczególnych gatunków grzybów rodzaju Alternaria i dużą zmienność sezonową w składzie gatunkowym populacji patogenu, co może wpływać na skuteczność ochrony (Osowski 2006; Kapsa 2009).

Celem badań przeprowadzonych w latach 2011-2012 było monitorowanie składu gatunkowego populacji grzybów rodzaju Alternaria na wybranych polach ziemniaka, w trzech różnych miejscowościach na północy Polski.

\section{Materiały i metody / Materials and methods}

Stężenie zarodników workowych grzybów rodzaju Alternaria w powietrzu, badano w latach 2011-2012, w trzech miejscowościach: Bonin i Mierzym (województwo zachodniopomorskie) oraz Przytocko (województwo pomorskie). Do pobierania zarodników grzyba zastosowano wytworzone samodzielnie pułapki (rys. 1). W każdej miejscowości, obracające się z wiatrem pułapki, przez które zasysane jest powietrze, umieszczono w łanie ziemniaków odmiany Bard (podatnej na alternariozę), na wysokości 90 i 150 centymetrów od powierzchni gleby. Zarodniki grzybów i pyłki roślinne unoszące się w zasysanym powietrzu osadzały się w środku pułapek na szkiełkach mikroskopowych pokrytych wazeliną. Kształt zarodników grzybów A. alternata i A. solani jest bardzo charakterystyczny dla gatunku i stosunkowo łatwy do rozróżnienia (rys. 2).

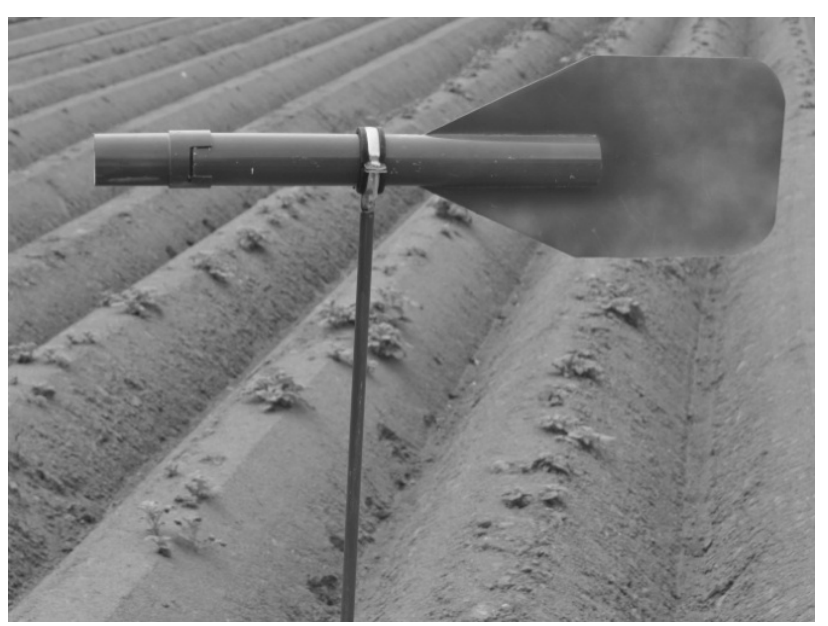

Rys. 1. Pułapka do wyłapywania zarodników Alternaria stosowana w badaniach

Fig. 1. Trap for catching of Alternaria spores used in the studies

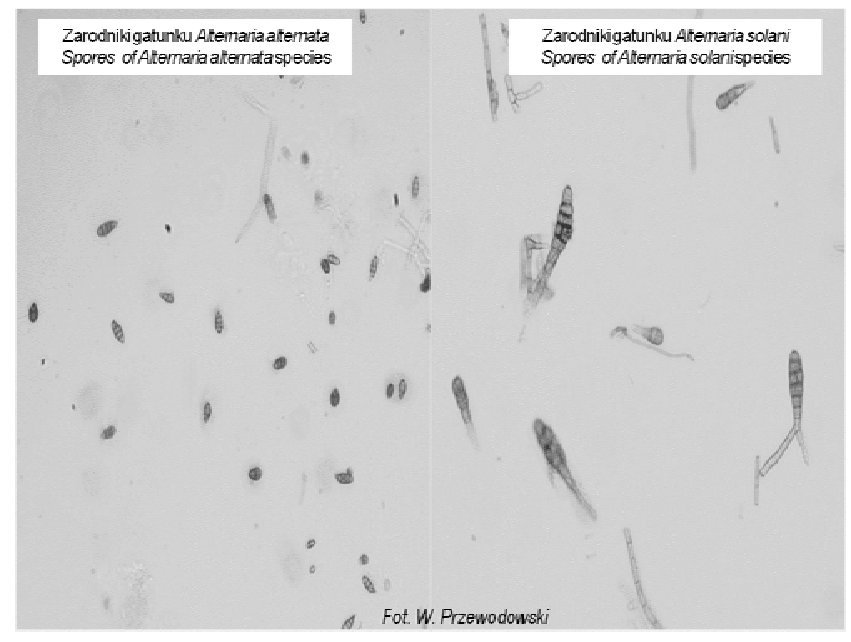

Rys. 2. Kształt i wielkość zarodników różnych gatunków Alternaria

Fig. 2. Shape and size of spores of various Alternaria species

Zawartość pułapek monitorowano w odstępach siedmiodniowych, od fazy zwarcia roślin w rzędach (BBCH 30-39) do zbioru plonu bulw (BBCH 90-99). Oceniano średnią liczbę zarodników osiadłych na powierzchni $1 \mathrm{~cm}^{2}$ szkiełek podstawkowych, wykładanych pojedynczo w pułapkach. Skład gatunkowy i liczbę odłowionych zarodników grzybów rodzaju Alternaria określano na bieżąco pod mikroskopem. 


\section{Wyniki i dyskusja / Results and discussion}

Wyniki monitorowania patogenów na plantacjach ziemniaka w ramach Programu Wieloletniego wykazały, że występowanie alternariozy jest powszechne. W latach 2008-2012 w warunkach Polski alternarioze spotykano, średnio na $81,9 \%$ obserwowanych plantacjach ziemniaka (tab. 1). Największą liczbę pól $\mathrm{z}$ objawami choroby stwierdzono w roku 2011 (93,5\% zaatakowanych plantacji), najmniej porażonych upraw obserwowano w 2012 roku $(71,0 \%$ plantacji). Monitorowanie alternariozy na terenie Polski w ostatnich latach wykazało zróżnicowany termin jej występowania w naszym kraju, w zależności od regionu (Kapsa 2007; Osowski 2007). W Polsce, w latach 2008-2012 najwcześniejsze objawy alternariozy obserwowano pod koniec maja i na początku czerwca (tab. 1). Wyniki obserwacji prowadzonych $\mathrm{w}$ innych krajach, wskazują że alternarioza pojawia się na wielu plantacjach Europy pod koniec okresu wegetacji (Hadders 2004; Wiik 2004), często po zarazie ziemniaka.

Tabela 1. Występowanie alternariozy w uprawach ziemniaka na terenie Polski w latach 2008-2012

Table 1. Occurrence of the early blight in potato crops in Poland in 2008-2012

\begin{tabular}{l|c|c|c}
\hline $\begin{array}{c}\text { Rok } \\
\text { Year }\end{array}$ & $\begin{array}{c}\text { Liczba obserwowanych } \\
\text { plantacji } \\
\text { Number of observed fields }\end{array}$ & $\begin{array}{c}\text { Obecność alternariozy } \\
\text { (\% obserwowanych plantacji) } \\
\text { Appearance of early blight } \\
\text { (\% of the observed fields) }\end{array}$ & $\begin{array}{c}\text { Data najwcześniejszego wystapienia } \\
\text { choroby w Polsce } \\
\text { Term of the earliest disease } \\
\text { appearance in Poland }\end{array}$ \\
\hline 2008 & 25 & 84,0 & 27.05 \\
\hline 2009 & 21 & 80,8 & 29.05 \\
\hline 2010 & 25 & 80,0 & 02.06 \\
\hline 2011 & 62 & 93,5 & 01.06 \\
\hline
\end{tabular}

Tabela 2. Terminy wystapienia objawów alternariozy na poletkach ziemniaka w miejscowościach prowadzenia badań Table 2. Dates of the appearance of early blight symptoms in potato fields in three locations of trials

\begin{tabular}{l|c|c|c}
\hline \multirow{2}{*}{$\begin{array}{c}\text { Lokalizacja badań } \\
\text { Location of trials }\end{array}$} & 2010 & 2011 & 2012 \\
\cline { 2 - 4 } & 24.06 & 21.06 & 18.06 \\
\hline Bonin & 23.06 & 20.06 & 20.06 \\
\hline Przytocko & 27.06 & 18.06 & 19.06 \\
\hline Mierzym &
\end{tabular}

Tabela 3. Liczba zarodników A. alternata (A.a.) i A. solani (A.s.) zebranych w populacji grzybów z rodzaju Alternaria Table 3. Number of A. alternata (A.a.) and A. solani (A.s.) spores collected within population of Alternaria genus

\begin{tabular}{|c|c|c|c|c|c|c|c|c|c|c|c|c|}
\hline \multirow{3}{*}{$\begin{array}{l}\text { Termin obserwacji } \\
\text { (tydzień/miesiąc) } \\
\text { Date of observation } \\
\text { (week/month) }\end{array}$} & \multicolumn{4}{|c|}{ Bonin } & \multicolumn{4}{|c|}{ Przytocko } & \multicolumn{4}{|c|}{ Mierzym } \\
\hline & \multicolumn{2}{|c|}{2011} & \multicolumn{2}{|c|}{2012} & \multicolumn{2}{|c|}{2011} & \multicolumn{2}{|c|}{2012} & \multicolumn{2}{|c|}{2011} & \multicolumn{2}{|c|}{2012} \\
\hline & A.a. & A.s. & A.a. & A.s. & A.a. & A.s. & A.a. & A.s. & A.a. & A.s. & A.a. & A.s. \\
\hline 1 & 2 & 3 & 4 & 5 & 6 & 7 & 8 & 9 & 10 & 11 & 12 & 13 \\
\hline II/06 & 1 & 0 & 4 & 0 & 25 & 0 & 16 & 0 & 3 & 0 & 3 & 0 \\
\hline III/06 & 24 & 4 & 5 & 0 & 9 & 0 & 1 & 0 & 4 & 2 & 0 & 0 \\
\hline IV/06 & 1 & 1 & 8 & 0 & 7 & 2 & 13 & 0 & 3 & 1 & 0 & 0 \\
\hline $\begin{array}{l}\Sigma \text { miesiąca } \\
\Sigma \text { of month }\end{array}$ & 25 & 5 & 17 & 0 & 41 & 2 & 30 & 0 & 10 & 3 & 3 & 0 \\
\hline $\mathrm{I} / 07$ & 40 & 7 & 0 & 0 & 18 & 5 & 3 & 0 & 28 & 1 & 0 & 2 \\
\hline $\mathrm{II} / 07$ & 53 & 16 & 53 & 2 & 54 & 5 & 30 & 3 & 46 & 0 & 6 & 1 \\
\hline III/07 & 119 & 5 & 25 & 7 & 71 & 5 & 103 & 6 & 34 & 0 & 103 & 8 \\
\hline IV/07 & 34 & 55 & 34 & 5 & 167 & 143 & 112 & 26 & 48 & 97 & 61 & 4 \\
\hline $\begin{array}{l}\Sigma \text { miesiąca } \\
\Sigma \text { of month }\end{array}$ & 246 & 83 & 112 & 14 & 310 & 158 & 248 & 35 & 156 & 98 & 170 & 15 \\
\hline $\mathrm{I} / 08$ & 284 & 182 & 114 & 22 & 47 & 38 & 101 & 7 & 142 & 11 & 78 & 7 \\
\hline
\end{tabular}




\begin{tabular}{|c|c|c|c|c|c|c|c|c|c|c|c|c|}
\hline 1 & 2 & 3 & 4 & 5 & 6 & 7 & 8 & 9 & 10 & 11 & 12 & 13 \\
\hline $\mathrm{II} / 08$ & 159 & 25 & 48 & 3 & 153 & 1 & 60 & 9 & 85 & 35 & 69 & 22 \\
\hline III/08 & 118 & 28 & 132 & 3 & 46 & 2 & 121 & 29 & 171 & 38 & 93 & 3 \\
\hline IV/08 & 35 & 62 & 142 & 25 & 134 & 3 & 62 & 9 & 144 & 67 & 92 & 23 \\
\hline $\begin{array}{l}\sum \text { miesiąca } \\
\sum \text { of month }\end{array}$ & 596 & 297 & 436 & 53 & 380 & 44 & 344 & 54 & 546 & 151 & 332 & 55 \\
\hline I/09 & 65 & 18 & 46 & 2 & 6 & 0 & 56 & 5 & 14 & 10 & 74 & 1 \\
\hline II/09 & 81 & 27 & 30 & 4 & 0 & 0 & 61 & 9 & 46 & 10 & 80 & 9 \\
\hline III/09 & 22 & 5 & 22 & 1 & 0 & 0 & 49 & 12 & 38 & 1 & 60 & 6 \\
\hline $\begin{array}{l}\Sigma \text { miesiąca } \\
\Sigma \text { of month }\end{array}$ & 168 & 50 & 98 & 7 & 6 & 0 & 166 & 26 & 98 & 21 & 214 & 16 \\
\hline
\end{tabular}

A.a. - A. alternata, A.s. - A. solani

W latach 2010-2012, pierwsze objawy choroby na poletkach doświadczalnych $\mathrm{w}$ poszczególnych lokalizacjach, w których pobierano próbki zarodników, wystąpiły stosunkowo późno, bo w 2-3 dekadzie czerwca (tab. 2). W obu miejscowościach w województwie zachodniopomorskim terminy pojawu alternariozy różniły się między latami o 6-9 dni, w Przytocku (województwo pomorskie) natomiast zaledwie o $3 \mathrm{dni}$.

W sezonie 2011 zebrano ogółem 3491 zarodników grzybów rodzaju Alternaria, natomiast w sezonie 2012 odnotowano ich mniej bo tylko 2445 (rys. 3). Liczba zarodników zbierana $\mathrm{w}$ poszczególnych miejscowościach była bardzo różna. W Boninie zebrano ich w latach 2011 i 2012 ogółem 1471 i 737, w Przytocku odpowiednio: 941 i 903, a w Mierzymiu 1079 i 805. W obu latach, zarówno w Boninie, Przytocku, jak i w Mierzymiu obserwowano więcej zarodników A. alternata w stosunku do A. solani (stosunek procentowy A.a.:A.s. w 2011 74:26, w $2012-89: 11)$.

Obserwowano wahania sezonowe występowania obu gatunków grzyba Alternaria. W obu latach, w zebranej populacji dominowały jednak zarodniki gatunku A. alternata przez cały sezon (rys. 4). Masowy wysyp zarodników obu gatunków obserwowano od końca lipca aż do końca sierpnia. Najczęściej zarodniki obu gatunków występowały w największym nasileniu równocześnie. Jedynie w sezonie 2011 w Przytocku obserwowano masowe stężenie zarodników A. solani w lipcu, a A. alternata w sierpniu.

Dokładniejsze, tygodniowe analizy zebranego materiału zarodnikowego wskazują na sezonowe zmiany w ilościowym i jakościowym składzie populacji grzybów (tab. 3). W populacjach obu gatunków grzybów (A.a. i A.s.) obserwowano 1-3 terminy masowego zarodnikowania $\mathrm{w}$ sezonie. Termin występowania, okres trwania i nasilenie zarodnikowania zależały od roku, miejscowości i gatunku obserwowanego grzyba. Najwcześniejsze szczyty zarodnikowania obserwowano dla grzyba A. alternataw 3. tygodniu lipca 2011 roku w Boninie i w 3. tygodniu lipca 2012 roku w Mierzymiu. W przypadku gatunku A. alternata szczyty masowego zarodnikowania grzyba notowano w sezonie częściej (2-3 razy) i trwały one dłużej (nawet do 3 tygodni). Ciekawą sytuację zaobserwowano w Przytocku. W obu latach badań masowe zarodnikowanie obu gatunków grzyba obserwowano w 4. tygodniu lipca.
Nie stwierdzono natomiast istotnych różnic $\mathrm{w}$ liczbie zarodników Alternaria i częstotliwości ich występowania na różnych wysokościach $\mathrm{w}$ łanie ziemniaka (wyniki z pułapek umieszczonych na wysokości 90 i $150 \mathrm{~cm}$ ).

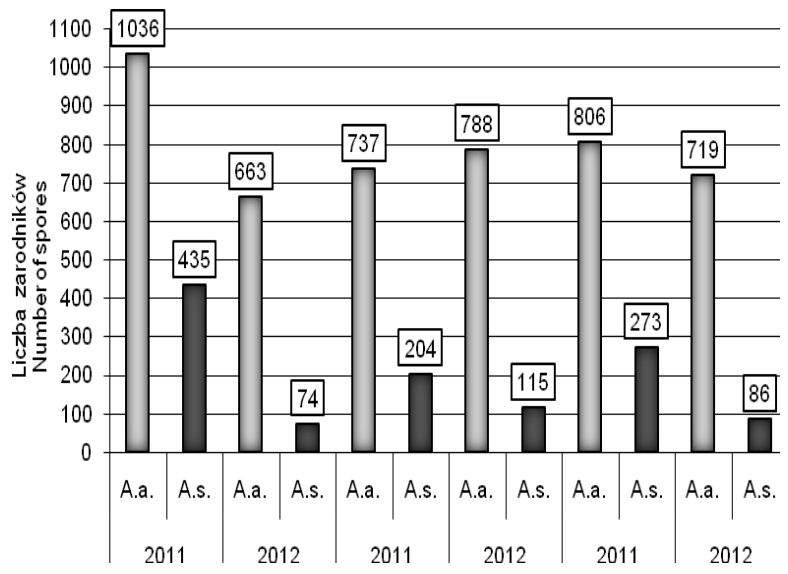

Rys. 3. Całkowita liczba zarodników A. alternata (A.a.) i A. solani (A.s.) zebranych w latach 2011 i 2012

Fig. 3. Total number of spores of A. alternata (A.a.) and A. solani (A.s.) collected in 2011 and 2012

Do tej pory nie prowadzono na szerszą skalę badań nad składem gatunkowym populacji grzybów rodzaju Alternaria na plantacjach ziemniaka w Europie. W badaniach niemieckich, oceniono izolaty pobrane jednorazowo w 34 miejscowościach. W analizowanych populacjach spotykano różne gatunki grzyba Alternaria; w większości jednak był to grzyb A. alternata (Hausladen i Leiminger 2007). W Polsce, badania tego typu, na niewielką skalę (jednoroczne, w jednej lokalizacji) przeprowadzono w Instytucie Hodowli i Aklimatyzacji Roślin - Państwowym Instytucie Badawczym, w Zakładzie Nasiennictwa i Ochrony Ziemniaka, w sezonie 2006, wykorzystując pułapkę Burkarda stanowiącą część polskiego systemu SPEC (System Prognozowania Epidemii Chorób), przeznaczonego do ochrony rzepaku. W sezonie wegetacyjnym analizowano fragmenty taśm $\mathrm{z}$ pułapki umieszczonej w Stacji Doświadczalnej Oceny Odmian w Rarwinie koło 


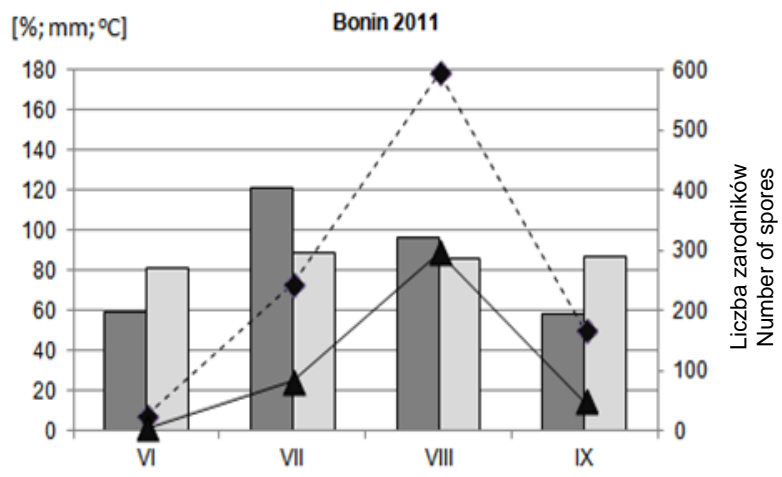

$\rightleftarrows$ Opad-Rainfall $\square$ Wilgotność-Humidity -.-A.a. $\longleftarrow$ A.s.

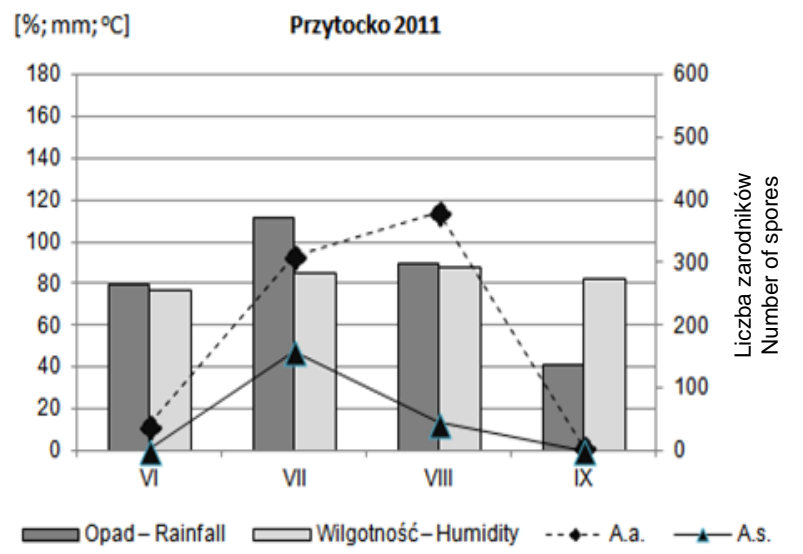

$\left[\% ; \mathrm{mm} ;{ }^{\circ} \mathrm{C}\right]$

Mierzym 2011

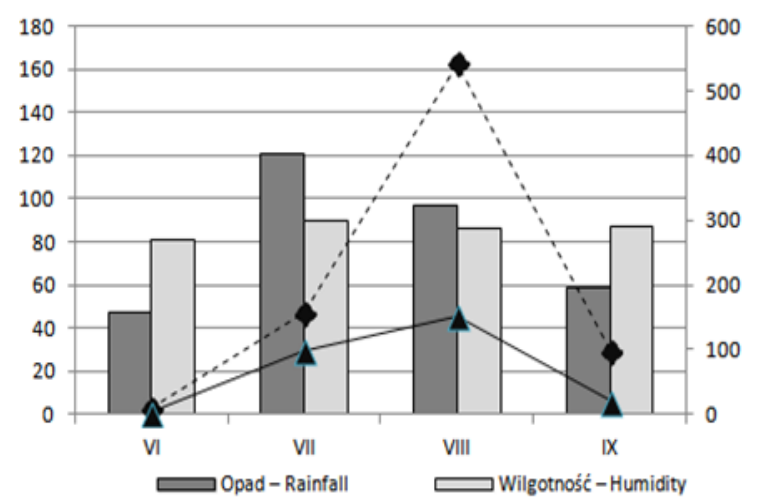

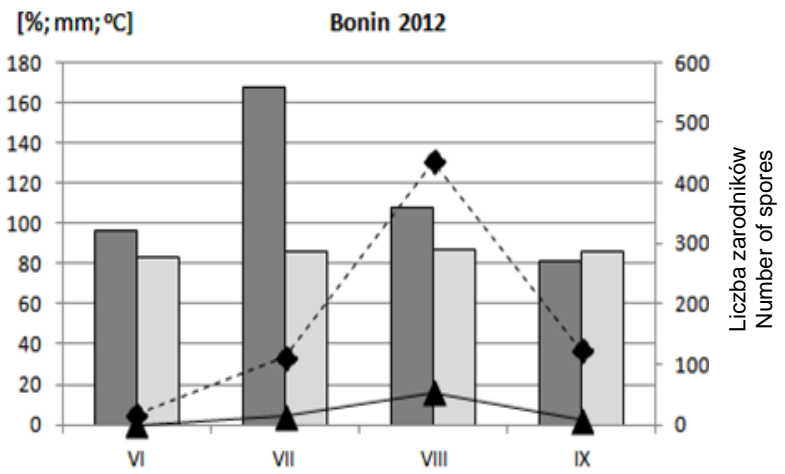

$\rightleftarrows$ Opad-Rainfall $\square$ Wilgotnośt́c-Humidity

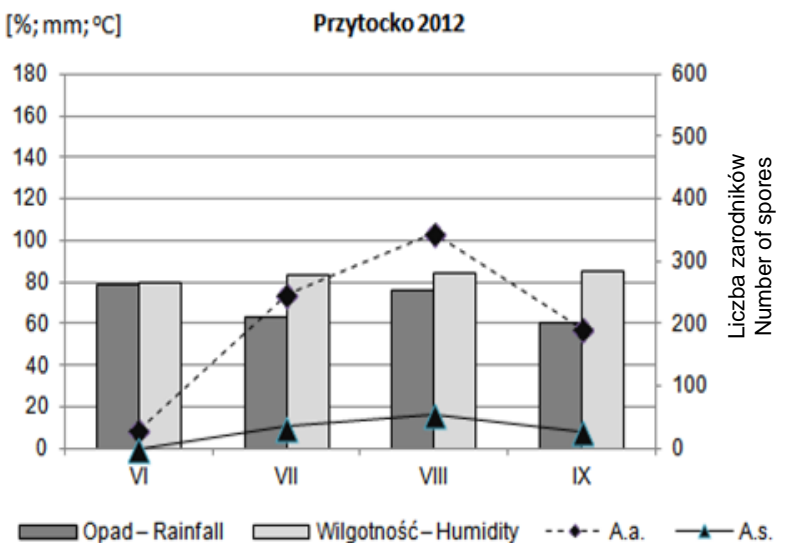

Rys. 4. Liczba zarodników różnych gatunków Alternaria schwytanych podczas sezonu 2011 i $2012 \mathrm{w}$ trzech lokalizacjach Fig. 4. Number of spores of various Alternaria species trapped during 2011 and 2012 seasons in three locations

Kamienia Pomorskiego, pobieranych w ciagu 10 tygodni (od 7 czerwca do 15 sierpnia). Wśród zarodników należących do różnych grzybów, stwierdzono obecność 1782 zarodników należących do rodzaju Alternaria. Wyniki analiz wykazały, że spośród tych zarodników - 82,7\% należało do grzyba A. alternata, a tylko $17,3 \%$ było zarodnikami charakterystycznymi dla $A$. solani. Obserwowano także wahania sezonowe w występowaniu obu gatunków grzyba
(Kapsa 2007; Kapsa i Osowski 2007). W innych badaniach nad składem populacji grzybów rodzaju Alternaria, wykonanych w latach 2008 i 2009, w trzech miejscowościach na północy kraju, wykazano z kolei dominację zarodników grzyba $A$. solani, które stanowiły 62,6\% badanej populacji (2352 zarodniki) w 2008 roku i 70,6\% badanej populacji (3041 zarodników) w sezonie 2009 łącznie w trzech miejscowościach (Osowski 2011). 
Ta zmienność wyników i ostatecznych wniosków przedstawianych $\mathrm{w}$ różnych badaniach wskazuje na potrzebę dalszych studiów prowadzonych jednakże według ujednoliconej, sprawdzonej metodyki, z wykorzystaniem profesjonalnego sprzętu, takiego jak pułapki zarodników. W najbliższych latach badania nad składem populacji grzybów - sprawców alternariozy będą kontynuowane w Boninie, przy użyciu specjalistycznych pułapek Burkarda, zakupionych przez firmę Bayer, która włączyła się do projektu. Badania te mogą stać się podstawą do opracowania modelu rozwoju patogenów dla potrzeb tworzenia systemów wspomagających podejmowanie decyzji w ochronie i polepszenia jej skuteczności w ograniczaniu rozwoju alternariozy.

\section{Wnioski / Conclusions}

1. Stosunek ilościowy, w jakim występują oba gatunki grzybów rodzaju Alternaria jest zmienny i zależny od wielu czynników, przede wszystkim od układu warunków pogodowych (lata badań) i siedliskowych (lokalizacje).

2. W latach 2011 i 2012 gatunkiem dominującym w populacjach grzybów rodzaju Alternaria okazał się grzyb A. alternata.

3. Największe zagrożenie wystąpienia alternariozy w uprawach ziemniaka na północy kraju występuje w okresie od połowy lipca do połowy sierpnia, kiedy obserwuje się maksymalny wysyp zarodników grzybów rodzaju Alternaria.

\section{Literatura / References}

Bouwmann J.J., Rijkers G. 2004. The control of Alternaria solani (early blight) with azoxystrobin in potatoes. p. 179-188. In: Special Report no. 10. (C.E. Westerdijk, H.T.A.M. Schepers, eds). Appl. Plant Res., Wageningen UR, PPO 333, 319 pp.

Gudmestad N.C., Pasche J.S. 2007. Role of fenamidone in the management of potato early blight - Alternaria solani. p. 175-182. In: Special Report no. 12. (H.T.A.M. Schepers, ed.). Appl. Plant Res., Wageningen UR, PPO 370, 368 pp.

Hadders J. 2004. Alternaria control in the USA and Egypt. p. 119-123. In: Special Report no. 10. (C.E. Westerdijk, H.T.A.M. Schepers, eds). Appl. Plant Res., Wageningen UR, PPO 333, 319 pp.

Hausladen H., Bässler E., Asensio N. 2004. Early blight of potato. p. 173-177. In: Special Report no. 10. (C.E. Westerdijk, H.T.A.M. Schepers, eds). Appl. Plant Res., Wageningen UR, PPO 333, 319 pp.

Hausladen H., Leiminger J. 2007. Potato early blight in Germany (Alternaria solani, Alternaria alternata). p. 189-194. In: Special Report no. 12. (H.T.A.M. Schepers, ed.). Appl. Plant Res., Wageningen UR, PPO 370, 368 pp.

Johnson K.B., Radcliffe E.B., Teng P. 1986. Effects of interacting populations of Alternaria solani, Verticillium dahliae and potato leaf hopper (Empascafabae) on potato yield. Phytopathology 76: 1046-1052.

Kapsa J. 2007. Zastosowanie pułapki Burkarda do określania składu gatunkowego rodzaju Alternaria w uprawach ziemniaka. Biul. IHAR 244: 223-229.

Kapsa J. 2009. Effectiveness of some fungicides in control of Alternaria alternata and Alternaria solani. p. 127-133. In: Special Report no. 13. (H.T.A.M. Schepers, ed.). Appl. Plant Res., Wageningen UR, PPO 384, 320 pp.

Kapsa J., Osowski J. 2004. Occurrence of early blight (Alternaria ssp.) at potato crops and results of its chemical control in Polish experiences. p. 101-107. In: Special Report no. 10. (C.E. Westerdijk, H.T.A.M Schepers, eds). Appl. Plant Res., Wageningen UR, PPO 333, 319 pp.

Kapsa J., Osowski J. 2007. Evaluation of performance of Burkard trap in identification of Alternaria species infecting potato crops. p. 183-188. In: Special Report no. 12. (H.T.A.M. Schepers, ed.). Appl. Plant Res., Wageningen UR, PPO 370, 368 pp.

Kuczyńska J. 1992. The influence of some factors on the incidence and harmfulness of early blight on potatoes. Biul. Inst. Ziemn. 41: $73-87$.

Leiminger J., Balmweg G., Hausladen H. 2010. Populations genetics - consequences on early blight diseases. p. 171-177. In: Special Report no. 14. (H.T.A.M. Schepers, ed.). Appl. Plant Res., Wageningen UR, PPO 396, 316 pp.

Nagaich B.B., Prased B. 1971. Interaction between Alternaria solani and potato wiruses X and Y. Indian J. Exper. Biol. 9 (1): 88-90.

Osowski J. 2006. Skuteczność wybranych fungicydów w ograniczaniu rozwoju grzybów z rodzaju Alternaria w badaniach laboratoryjnych. s. 23-25. W: Nasiennictwo i Ochrona Ziemniaka. Konferencja Naukowo-Szkoleniowa. IHAR ZNiOZ Bonin, Kołobrzeg, 30-31 marca 2006, 130 ss.

Osowski J. 2007. Termin wystapienia pierwszych objawów alternariozy ziemniaka w zależności od roku i województwa. [Date of the first appearance of Elary blight symptoms depending on year and voivodship]. Prog. Plant Prot./Post. Ochr. Roślin 47 (2): $216-223$.

Osowski J. 2011. Badania nad występowaniem alternariozy (Alternaria spp.) na plantacjach ziemniaka w zależności od warunków meteorologicznych i możliwości ograniczania jej rozwoju. Praca doktorska IHAR-PIB w Radzikowie, Bonin, 119 ss.

Rotem J. 1966. Variability in Alternaria porri f. solani. Israel J. Bot. 15: 48-57.

Shtienberg D., Blachinsky D., Ben-Hador G., Dinoor A. 1996. Effects of growing season and fungicide type on the development of Alternaria solani and on potato yield. Plant Dis. 80: 994-998.

Wiik L. 2004. Potato early blight in Sweden: Results from recent field trials. p. 109-118. In: Special Report no. 10. (C.E. Westerdijk, H.T.A.M. Schepers, eds). Appl. Plant Res., Wageningen UR, PPO 333, 319 pp. 